\title{
Phylogeography of the brittle star Ophiura sarsii Lütken, 1855 (Echinodermata: Ophiuroidea) from the Barents Sea and East Atlantic
}

\section{Evgeny Genelt-Yanovskiy, ${ }^{1, *}$ Yixuan $\mathbf{L i}^{2}$, Ekaterina Stratanenko ${ }^{3}$, Natalia Zhuravleva ${ }^{3}$, Natalia Strelkova ${ }^{4}$, Qinzeng $\mathrm{Xu}^{2}$, Sophia Nazarova ${ }^{3, * *}$}

1 - Department of Molecular Systematics, Zoological Institute Russian Academy of Sciences, Saint Petersburg

2 - MNR Key Laboratory of Marine Eco-Environmental Science and Technology, First Institute of Oceanography, Ministry of Natural Resources, Qingdao, 266061, China

3 - Laboratory of Marine research, Zoological Institute Russian Academy of Sciences, Saint Petersburg 4 - Laboratory of Hydrobiology, Polar branch of "VNIRO" ("PINRO" named after N.M.Knipovich), Murmansk, Russian Federation

*genelt-yanovskiy@gmail.com

** sophia.nazarova@gmail.com

\begin{abstract}
Ophiura sarsii is a common brittle star species across Arctic and subarctic regions of Atlantic and Pacific oceans. In the Barents Sea $O$. sarsii is among the dominant echinoderms. We studied genetic diversity of $O$. sarsii by sequencing the $548 \mathrm{bp}$ fragment of mitochondrial COI gene. $O$. sarsii demonstrated high genetic diversity in the Barents Sea. Both major Atlantic mtDNA lineages were present in the Barents Sea and were evenly distributed between the northern waters around Svalbard archipelago and the southern part near Murmansk coast of Kola Peninsula. Both regions, as well as other parts of the $O$. sarsii range, were characterized by high haplotype diversity with a significant number of private haplotypes, being mostly satellites to the two dominant haplotypes, each belonging to a different mtDNA clade. Demographic analyses indicated that the demographic and spatial expansion of Ophiura sarsii in the Barents Sea most plausibly has started during the Bølling-Allerød interstadial, during the deglaciation of the western margin of the Barents Sea.
\end{abstract}

Keywords

Ophiura sarsii, the Barents Sea, brittle stars, barcoding, COI gene

\section{Introduction}

Marine communities of the Northern Atlantic experienced remarkable changes during the Quaternary sea level oscillations, when ranges of species were contracting during the advances of glaciations and expanding during warmer periods (Wares \& Cunningham, 2001 etc). Also, several taxa migrated from the Pacific by transarctic migrations (Laakonen et al., 2020 etc.). While historical ecology of nearhore and intertidal ecosystems are being extensively studied (Colson, \& Huges, 2006; Rock et al., 2007; Luttikhuizen et al., 2008; Maggs et al., 2008; Krebes et al., 2011; 
Genelt-Yanovskiy et al., 2019), our understanding of phylogeography and population structure in deep-sea benthic organisms remains understudied. Subtidal species in the North Atlantic demonstrated different genetic patterns. Sea urchins Strongylocentrotus droebachiensis, bivalves Arctica islandica and Modiolus modiolus have common haplotypes for Eastern and Western North Atlantic (Addison \& Hart, 2005; Dahlgren et al., 2000; Halanych et al., 2013). Contrast patterns with two monophyletic clades for the Eastern and Western North Atlantic show gastropods Buccinum undatum (Magnúsdóttir et al., 2019).

The Barents Sea is a marginal sea of the Arctic Ocean and a biogeographic transition zone between East Atlantic and polar faunas. The sea is highly productive, yet there is a pronounced spatial variation in productivity of benthic communities with higher abundance and biomass in southern and central parts then in northern regions around Svalbard and Frans Josef Land (Cochrane et al., 2009). The northern Barents Sea is often considered as the Arctic warming hotspot, where sharp increase of water temperatures and salinity is observed since the mid-2000s (Lind et al., 2018). Studies of population structure of species distributed across the Barents Sea shelf is thus important for understanding the current and long-term changes in this dynamic marine ecosystem.

The Ophiuroidea are important components of marine benthic communities in the Northern Hemisphere, often dominating vast areas of marine shelves (Piepenburg \& Schmid, 1996; Blachard et al., 2013; Ravelo et al., 2017). The brittle star Ophiura sarsii Lütken, 1855 is a circumpolar cold-water species widely distributed throughout the North Pacific, North Atlantic, and Arctic oceans where it can reach depths of ca. $3000 \mathrm{~m}$ (Djakonov 1954; Anisimova 2000). In the Barents Sea, $O$. sarsii represent up to $4 \%$ of total echinoderm biomass, typically occurring at muddy and muddy fine sand communities at a depth range between 3 and 500 meters (Anisimova 2000). O. sarsii is a predator-scavenger species, and an important food item for many fish species (Packer et al., 1994). It is also a typical marine broadcast spawner species, spawning in the Barents Sea in May-June (Kuznecov, 1963) and then having a feeding larva (ophiopluteus) with planktonic existence of up to 30 days (Dautov \& Selina 2009).

Genetic structure of the $O$. sarsii were investigated in detail only in the Pacific region (Li et al., 2020). But data from the Atlantic are solitary, when this species were used in barcoding studies (Khodami et al., 2014; Laakmann et al., 2016; Layton et al., 2016). Here we presented the pilot study of the mtDNA variation in $O$. sarsii populations from the Barents Sea.

\section{Materials and Methods}

\section{Samples}

Sampling was conducted during the 17-th joint Barents Sea Ecosystem Survey (BESS) cruise of Institute of Marine Research (IMR, Norway) and Polar branch of the VNIRO (PINRO, Russia) (Michalsen et al. 2013) in September 2019 and 114 cruise RV "Vilnus" (Polar branch of the VNIRO) (Fig. 1). Brittle stars were sampled by the bottom trawl from the depth 84-325 m (Table 1). Individuals from the trawl were washed in seawater from sediments and preserved in $96 \%$ ethanol. Specimens of Ophiura sarsii from the Barents Sea are deposited in the Zoological Institute (ZIN RAS) in St. Petersburg. 
Also, twenty-three $O$. sarsii cytochrome oxidase subunit I (COI) gene sequences from Atlantic region were mined from NCBI GenBank for the phylogeographic and demographic analyses. These samples corresponded to the following regions: Iceland (KJ620617 - KJ620623), Baffin Sea (KU495754, KU495764, KU495803), Hudson Bay (KU495767, KU495777, KU495813, KU495897), North Sea (KX459083 - KX459088), St.Lawrence Bay (MG421803, MG422945) and Danish Straits (MG934897, MG935229).

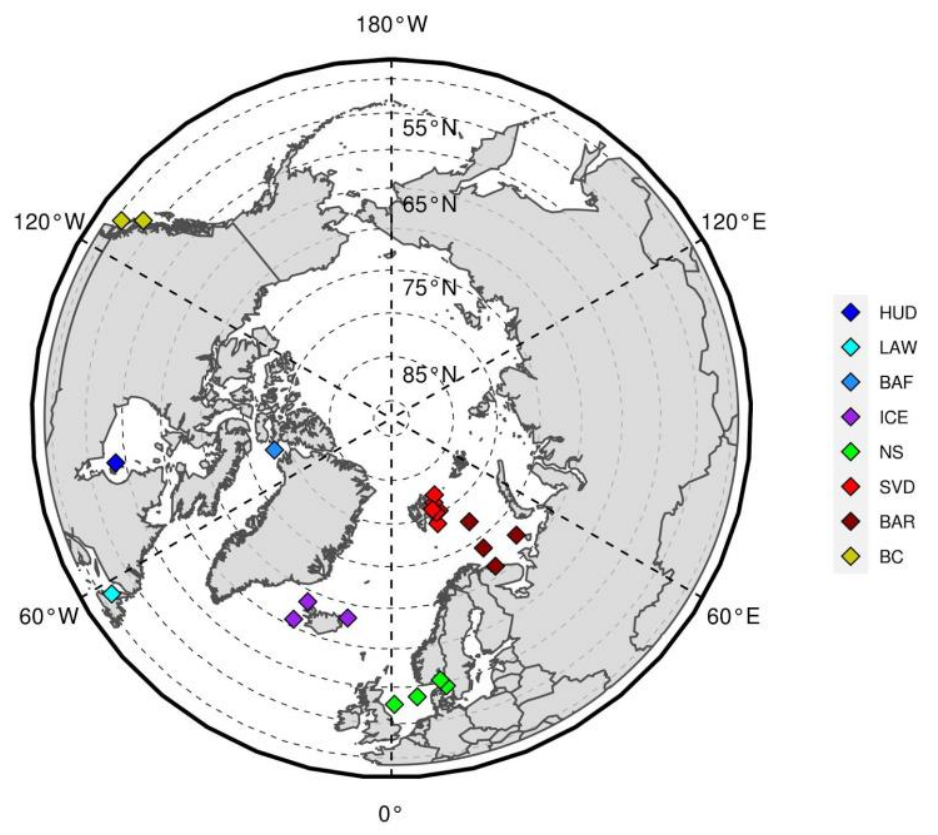

Figure 1. Map of the Ophiura sarsii sampling. Locations codes: HUD - Hudson Bay, LAW St.Lawrence Bay, BAF - Baffin Bay, ICE - Iceland, NS - North Sea, SVD - Svalbard, BAR Southern part of the Barents Sea, BC - British Columbia.

\section{DNA extraction, PCR, and sequencing}

Total genomic DNA was extracted from the arm tissues using the QIAamp Fast DNA Tissue Kit (QiaGen). Newly designed forward primer OphS_COI_full_F (TTC TAC CAA CCA TAA GGA TAT AGG G) with HCO-2198 (TAA ACT TCA GGG TGA CCA AAA AAT CA) (0. Folmer et al. 1994) were used to amplify a $700 \mathrm{bp}$ fragment of cytochrome oxidase (COI) gene. PCR amplifications were carried out with a BioRad T-100 cycler. Each PCR reaction mixture (volume $25 \mu \mathrm{l})$ contained $3 \mu \mathrm{l}$ template DNA, $5 \mu \mathrm{l}$ RCR master-mix ScreenMix-HS (Evrogen), $13 \mu 1$ nuclease-free water, and $2 \mu \mathrm{l}$ each primer $(10 \mathrm{pmol})$. The amplification reaction was performed with an initial denaturation step of $2 \mathrm{~min}$ at $94^{\circ} \mathrm{C}$, followed by 40 cycles of $94^{\circ} \mathrm{C}$ denaturation for $30 \mathrm{~s}, 52^{\circ} \mathrm{C}$ annealing for $60 \mathrm{~s}, 72^{\circ} \mathrm{C}$ extension at $60 \mathrm{~s}$, and a final $7 \mathrm{~min}$ extension at $72^{\circ} \mathrm{C}$ during the last cycle. Amplified fragments of each individual were sequenced in both directions at Evrogen (Russia). 
Following the pairwise alignments of 5' -3' and 3-' 5' individual sequence reads, all polymorphisms were double-checked on the raw chromatograms. Sequences of this study are available from GenBank (accession numbers MW376210-MW376262).

Table 1. Ophiura sarsii sampling information.

\begin{tabular}{|c|c|c|c|c|c|c|c|c|}
\hline ID & Cruise code & Data & Station & Area & Latitude & Longitude & $\begin{array}{c}\text { Depth, } \\
\text { m }\end{array}$ & $\mathbf{N}$ ind \\
\hline Oph $41-47$ & \multirow{7}{*}{ J.Hjort-2019 } & 15.09.2019 & 2348 & \multirow{6}{*}{ Svalbard } & $76^{\circ} 56^{\prime} 9,88^{\prime \prime} \mathrm{N}$ & $23^{\circ} 44^{\prime} 7,047^{\prime \prime} \mathrm{E}$ & 84 & 7 \\
\hline Oph 52 & & 21.09.2019 & 2376 & & $78^{\circ} 12^{\prime} 35,63^{\prime \prime} \mathrm{N}$ & $27^{\circ} 20^{\prime} 9,555^{\prime \prime} \mathrm{E}$ & 325 & 1 \\
\hline Oph $53-61$ & & 25.09.2019 & 2394 & & $79^{\circ} 18^{\prime} 35,67^{\prime \prime} \mathrm{N}$ & $26^{\circ} 47^{\prime} 45,57^{\prime \prime} \mathrm{E}$ & 258 & 9 \\
\hline Oph $62-64$ & & 21.09.2019 & 2378 & & $78^{\circ} 09^{\prime} 09,49^{\prime \prime} \mathrm{N}$ & $25^{\circ} 34^{\prime} 16,51^{\prime \prime} \mathrm{E}$ & 136 & 3 \\
\hline Oph $65-72$ & & 25.09.2019 & 2395 & & $80^{\circ} 04^{\prime} 8,523^{\prime \prime} \mathrm{N}$ & $29^{\circ} 23^{\prime} 45,57^{\prime \prime} \mathrm{E}$ & 319 & 8 \\
\hline Oph $73-80$ & & 23.09.2019 & 2387 & & $78^{\circ} 41^{\prime} 8,276^{\prime \prime} \mathrm{N}$ & $24^{\circ} 14^{\prime} 41,47^{\prime \prime} \mathrm{E}$ & 150 & 8 \\
\hline Oph $48-51$ & & 31.08 .2019 & 2274 & \multirow{4}{*}{$\begin{array}{c}\text { Southern } \\
\text { Barents } \\
\text { Sea }\end{array}$} & $75^{\circ} 15^{\prime} 22,64^{\prime \prime} \mathrm{N}$ & $37^{\circ} 00^{\prime} 6,18^{\prime \prime} \mathrm{E}$ & 178 & 4 \\
\hline Oph81 & diver sampling & 19.08.2019 & - & & $69^{\circ} 10,388^{\prime} \mathrm{N}$ & $35^{\circ} 07,907^{\prime} \mathrm{E}$ & 10 & 1 \\
\hline $\begin{array}{c}\text { Oph119 - } \\
125\end{array}$ & \multirow{2}{*}{ Vilnus 2020} & 08.03 .2020 & 86 & & $70^{\circ} 21^{\prime} 4^{\prime \prime} \mathrm{N}$ & $46^{\circ} 56^{\prime} 1^{\prime \prime} \mathrm{E}$ & $107-103$ & 7 \\
\hline $\begin{array}{c}\text { Oph } 126- \\
136\end{array}$ & & 22.02 .2020 & 6 & & $71^{\circ} 47^{\prime} 1^{\prime \prime} \mathrm{N}$ & $35^{\circ} 21^{\prime} 1 " \mathrm{E}$ & $252-255$ & 11 \\
\hline
\end{tabular}




\section{Molecular analysis}

Sequences were aligned by Muscle 3.8.425 (Edgar 2004) as implemented in Geneious Prime® 2020.1.2. The mtDNA diversity was firstly illustrated with Bayesian Inference phylogenetic tree reconstruction, for which the GTR+I+G model was selected by JModelTest 2.1.10 (Darriba et al., 2012). Bayesian tree reconstruction was performed in MrBayes 3.2.6 (Ronquist et al., 2012). Analysis started with random trees and performed with four independent Markov Chain Monte Carlo (MCMC) chains for 100000 generations with sampling every 100th generation, the standard deviations of split frequencies were below 0.01 ; potential scale reduction factors were equal to 1.0; stationarity was examined in Tracer v1.7 (Rambaut et al., 2018). A consensus tree was constructed based on the trees sampled after the $25 \%$ burn-in. Mean pairwise distances within and between the two species were calculated using MEGA X (Kumar et al., 2018). Sequences of Ophiura kinbergi (NCBI accession No MN183291) and Ophiura robusta (NCBI accession No MG935300).

Descriptive genetic statistics and haplotype analysis were used with R-package pegas (Paradis, 2010). Haplotype network was built using an infinite site model (uncorrected or Hamming distance) of DNA sequences and pairwise deletion of missing data as implemented in pegas R package (Paradis, 2010). The neutrality tests, Tajima' D (Tajima, 1989) and Fu' Fs (Fu, 1996), were conducted for each of the major haplotype groups present in the Barents Sea.

To test departures from a constant population size, three approaches were used. Firstly, the Tajima's D and Fu's Fs neutrality tests were calculated in DNAsp v6 (Rozas et al., 2017) for each of the major East Atlantic mtDNA lineages occuring in the Barents Sea. The demographic history was further assessed by constructing pairwise mismatch distributions in DNAsp. For the major mitochondrial lineages, the demographic parameter tau $(\tau)$ was calculated using DNAsp software to infer the time since regional population expansion. The time since the start of population expansion was calculated as $t=\tau / 2 \mu$, where $t$ is a number of years since population expansion, $\tau$ represents a unit of mutational time and $\mu$ is the per locus per year mutation rate (Rogers $\&$ Harpending, 1992). Finally, the coalescent-based Bayesian skyline plots (BSP) using BEAUti v 2 and BEAST v 2.6.3 (Bouckaert et al., 2014). For BSP priors included the implementation of the GTR substitution model defined by jModelTest, a strict clock model, and the constant skyline model. For both mismatch and BSP analyses, a mutation rate of $2.48^{*} 10^{-8}$ per lineage per year (2.48\% per million years) was used for the COI, following other studies in Ophiuroidea (Naughton et al., 2014; Sands et al., 2015).

\section{Results}

The total aligned COI data set consisted of 548 nucleotide positions for 76 Ophiura sarsii sequences, including 53 newly obtained sequences from the Barents Sea and earlier published sequences deposited in GenBank (Khodami et al., 2014; Laakmann et al., 2016; Layton et al., 2016).

Bayesian tree reconstruction demonstrated that $O$. sarsii from Hudson Bay grouped with Pacific sequences from British Columbia (Fig.2), and were sister to a major group of $O$. sarsii sequences. Atlantic diversity of $O$. sarsii was represented by two highly supported mitochondrial lineages that were distinguished by a $2.5 \%$ estimated sequence distance in COI (Maximum composite likelihood model). Both mitochondrial lineages were present in the Barents Sea, yet the clade 1 also included 
four sequences from West Atlantic (Baffin Island and St.Lawrence Bay), while clade 2 included more $O$. sarsii sequences from the North Sea. Nevertheless, since our quantitative sampling was limited to the Barents Sea, no clear segregation of local East Atlantic samples into two major mitochondrial lineages was found.

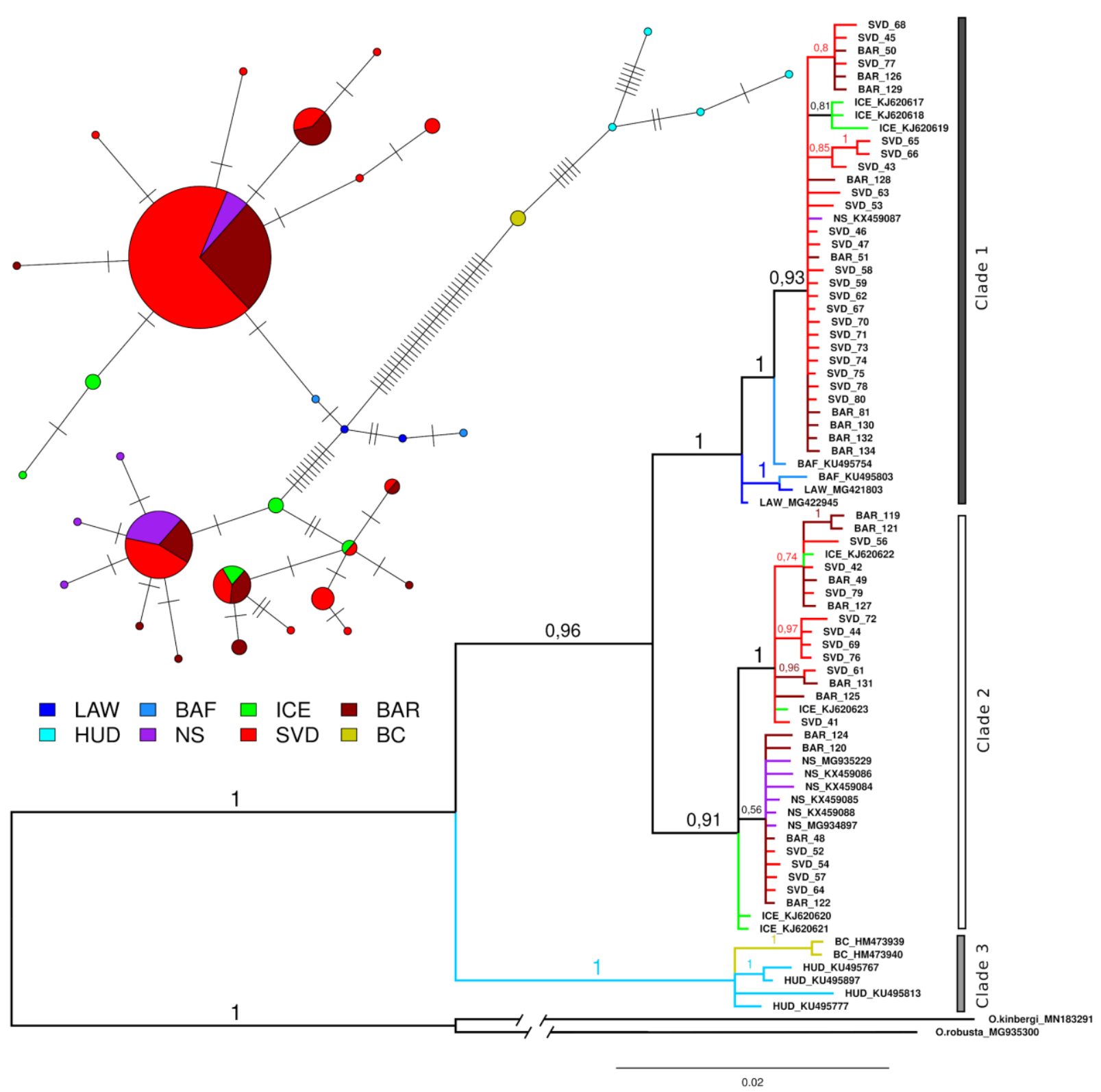

Figure 2. Mitochondrial diversity in Ophiura sarsii. Bayesian consensus tree and haplotype Hamming distance network.

Across the Atlatic, the nucleotide diversity ranged from 0.0097 (North Sea) to 0.0383 (Canada) (Table 2). Among 35 identified COI O. sarsii haplotypes, 15 were new in the Atlantic. O. sarsii mtDNA diversity in the Barents Sea consisted of 18 COI haplotypes, including 5 haplotypes shared between northern (SVD) and southern (BS) parts of the sea. In total, 14 COI haplotypes were 
registered in SVD, of which 8 were private. Similarly, 5 of 10 haplotypes observed in BS were private. Haplotype diversity (HD) was high (>0.84) among all studied regions and samples (Table 2).

Table 2. Estimates of genetic diversity in Ophiura sarsii samples. N - sample size, Ht - total number of haplotypes, $\mathrm{Hp}$ - number of private haplotypes, $\mathrm{H}$ - haplotype diversity, pi - nucleotide diversity

\begin{tabular}{|l|l|l|l|l|l|l|l|l|}
\hline \multicolumn{1}{|c|}{ Location } & \multicolumn{1}{|c|}{ Code } & N & Ht & Hp & H & (SD) & pi & (SD) \\
\hline Svalbard & SVD & 34 & 14 & 8 & 0.840 & 0.0030 & 0.0138 & 0.00005 \\
\hline Southern Barents Sea & BAR & 19 & 10 & 5 & 0.906 & 0.0017 & 0.0148 & 0.00006 \\
\hline Iceland & ICE & 7 & 5 & 3 & 0.905 & 0.0070 & 0.0138 & 0.00007 \\
\hline North Sea \& Danish Strait & NS & 8 & 6 & 4 & 0.893 & 0.0104 & 0.0097 & 0.00004 \\
\hline Canada & LAW, BAF, HUD & 8 & 8 & 8 & 1.000 & 0.0020 & 0.0383 & 0.00047 \\
\hline
\end{tabular}

The haplotype network revealed the presence of three different haplotype clusters separated by more than five substitutions (Fig. 2). First cluster was mostly represented by a single star-shaped group of haplotypes from the Barents Sea (SVD, BAR), Iceland (ICE) and the North Sea, and was two mutation steps apart from the haplotypes from the Canadian Arctic (BAF, LAW). Second cluster also included haplotypes from the North Sea (NS), Barents Sea (SVD, BAR) and Iceland (ICE) and was more complex with several dominant haplotypes with adjacent satellite singletons connected by 1 substitution. Third cluster of haplotypes was fully attributed to the Hudson's Bay. First and second haplogroups were separated by 11 substitutions, while second and third clusters were separated by 33 mutation steps.

To test the presence of population structure and identify the homogenous groups for the subsequent demographic analyses, a series of AMOVA analyses was implemented. Firstly, AMOVA was implemented on a complete dataset, where two Barents Sea samples (BAR and SVD) were grouped together; four West Atlantic sequences (BAF and LAW) as well as Pacific and Hudson Bay (BC and HUD) were combined in corresponding samples; Iceland and the North Sea were left as individual samples. AMOVA showed that $57 \%$ of total variance was distributed among groups, $43 \%$ variance within populations with only $0.28 \%$ among populations within groups (Table 3 ). A separate AMOVA test (Table 3) did not show internal heterogeneity between brittle stars from SVD and BAR samples. As no clear population structure was revealed among East Atlantic samples, demographic analyses were implemented for each of the two major $O$. sarsii haplotype clades. Samples from the West Atlantic, Pacific and Hudson Bay were excluded from the subsequent analyses. Thus, clade 1 was represented by a star-shaped pattern formed by dominant Barents Sea haplotype, and satellite haplotypes from Barents Sea and Iceland; clade 2 was represented by two sub-dominant haplotypes shared between Barents Sea, North Sea and Iceland (see Fig.2 and right indent on Fig.4 for details). 
The neutrality Tajima' D index was not significantly different from zero for both clade $1(\mathrm{D}=$ $1.596, p=0.56)$, and clade $2(\mathrm{D}=-0.950, \mathrm{p}=0.59)$. Fu's Fs was significantly negative for both clade $1(\mathrm{Fs}=-6.26, \mathrm{p}=0.002)$ and clade $2(\mathrm{Fs}=-6.58, \mathrm{p}=0.001)$, indicating population expansion. The mismatch distribution for the clade 1 was unimodal and bimodal for the clade 2 showing peaks at 1 and 4 differences (Fig. 3).

Table 3. Results of the AMOVA analysis for Atlantic populations of Ophiura sarsii.

\begin{tabular}{|c|c|c|c|c|c|c|}
\hline Source of variation & d.f. & $\begin{array}{c}\text { Sum of } \\
\text { squares }\end{array}$ & $\begin{array}{c}\text { Variance } \\
\text { components }\end{array}$ & $\begin{array}{c}\% \text { of } \\
\text { variation }\end{array}$ & $\begin{array}{c}\text { Fixation } \\
\text { index }\end{array}$ & $p$-value \\
\hline \multicolumn{7}{|c|}{ Complete O. sarsii dataset } \\
\hline Among groups & 4 & 194.012 & $4.64768 \mathrm{Va}$ & 56.82 & 0.56824 & 0.065 \\
\hline $\begin{array}{c}\text { Among samples } \\
\text { within groups }\end{array}$ & 1 & 4.068 & $0.02294 \mathrm{Vb}$ & 0.28 & 0.0065 & 0.297 \\
\hline Within samples & 71 & 249.102 & $3.50848 \mathrm{Vc}$ & 42.9 & 0.57104 & $0.000^{\star *}$ \\
\hline \multicolumn{7}{|c|}{ Ophiura sarsii from Svalbard and Southern Barents Sea } \\
\hline Among samples \\
within group
\end{tabular}

Star-shape of clade 1 with the unimodal mismatch distribution and the significantly negative values of Tajima' D and Fu's Fs tests indicated a recent expansion of this clade. Conversion of demographic parameter $\tau$ into years was performed using the 2,48\% per MY divergence rate (Naughton et al., 2014) and sequence length of $547 \mathrm{bp}\left(\mu=2.8^{*} 10^{-8} * 547=0.0000136\right)$. Considering $\tau=1.039$, the expansion time for clade (1) was calculated as 38295 years BP. Similarly, for the clade 2 demographic parameter $\tau$ was estimated as 2.350 , and time since last population expansion was calculated as 86616 years BP. The clade 2 itself is complex and consists of several abundant haplotypes forming star-like patterns with one dominant haplotype and several satellites differing by one or two nucleotide substitutions. We thus additionally calculated time since past population expansion for the biggest star-like pattern within clade 2 . Mismatch analysis (not shown) yielded a demographic parameter $\tau$ equal to 0.858 , and time since last population expansion was calculated as 31624 years BP. Bayesian Skyline Plots further confirmed demographic expansion for both clades of $O$. sarsii, yielding in younger median estimates of time since last population expansion as ca. 18000 years BP for clade 1 and ca. 58000 years for clade 2. 


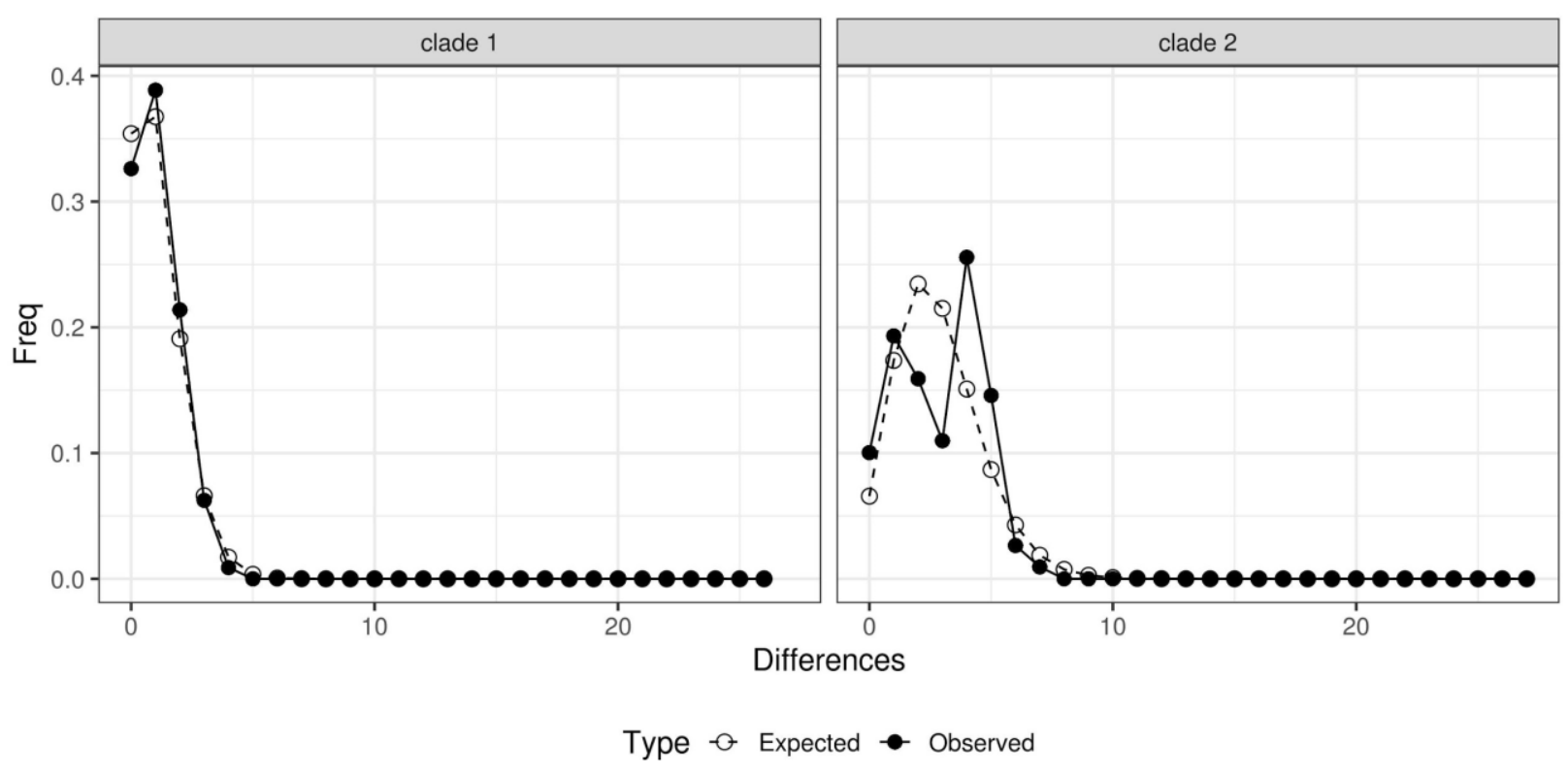

Figure 3. MtDNA mismatch distributions for two main haplotype clades of Ophiura sarsii in East Atlantic

\section{Discussion}

Our study revealed two major mitochondrial lineages in Atlantic Ophira sarsii, while no clear population structure was found across East Atlantic. O. sarsii sequences from Hudson Bay appeared to be closer to the Pacific than the Atlantic samples. Our findings corroborate the results of recent study of Pacific populations of $O$. sarsii indicating multiple mtDNA lineages across the species range with one from Yellow Sea identified as separate subspecies, O. sarsii vadicola previously described on the basis of morphological features (Li et al., 2020). Atlantic-Pacific lineage divergence is typical for most amphi-boreal and subarctic marine species (Laakkonen et al., 2020 and references therein). Bayesian tree reconstruction and haplotype network also indicated that West Atlantic $O$. sarsii sequences formed a compact cluster being sister to the East Atlantic sequences within the clade 1, yet only four sequences were available from the region. Several intertidal and subtidal amphi-Atlantic species demonstrates pronounced divergence between West and East Atlantic haplotypes (Wares \& Cunningman 2001; Magnúsdóttir et al., 2019), but cases of shared haplotypes and lineages between two parts of the Atlantic are also common in e.g. sea star Asterias rubens (Wares \& Cunningman 2001), quahog Arctica islandica (Dahlgren et al., 2000) and Modiolus modiolus (Halanych et al., 2013).

O. sarsii demonstrated high genetic diversity in the Barents Sea. Both major Atlantic mtDNA lineages were present in the Barents Sea and evenly distributed between the northern waters around Svalbard archipelago and the southern part near Murmansk coast of Kola Peninsula. Both regions, as well as other parts of the $O$. sarsii range, were characterized by high haplotype diversity with a significant number of private haplotypes, being mostly satellites to the two dominant haplotypes, 
each belonging to a different mtDNA clade. High mtDNA diversity has recently been recorded in Svalbard populations of intertidal North Atlantic amphipods Gammarus (Grabowski et al., 2019) and in the Barents and White Sea populations of amphi-boreal pacific herring Clupea pallasii (Laakkonen et al., 2013). On the contrary, typical boreal Atlantic intertidal species demonstrate a gradual northward decline of abundance and genetic diversity with Barents Sea populations being largely dependent on long-distance larval dispersal from source populations of the Norwegian Sea (Genelt-Yanovskiy et al., 2019).

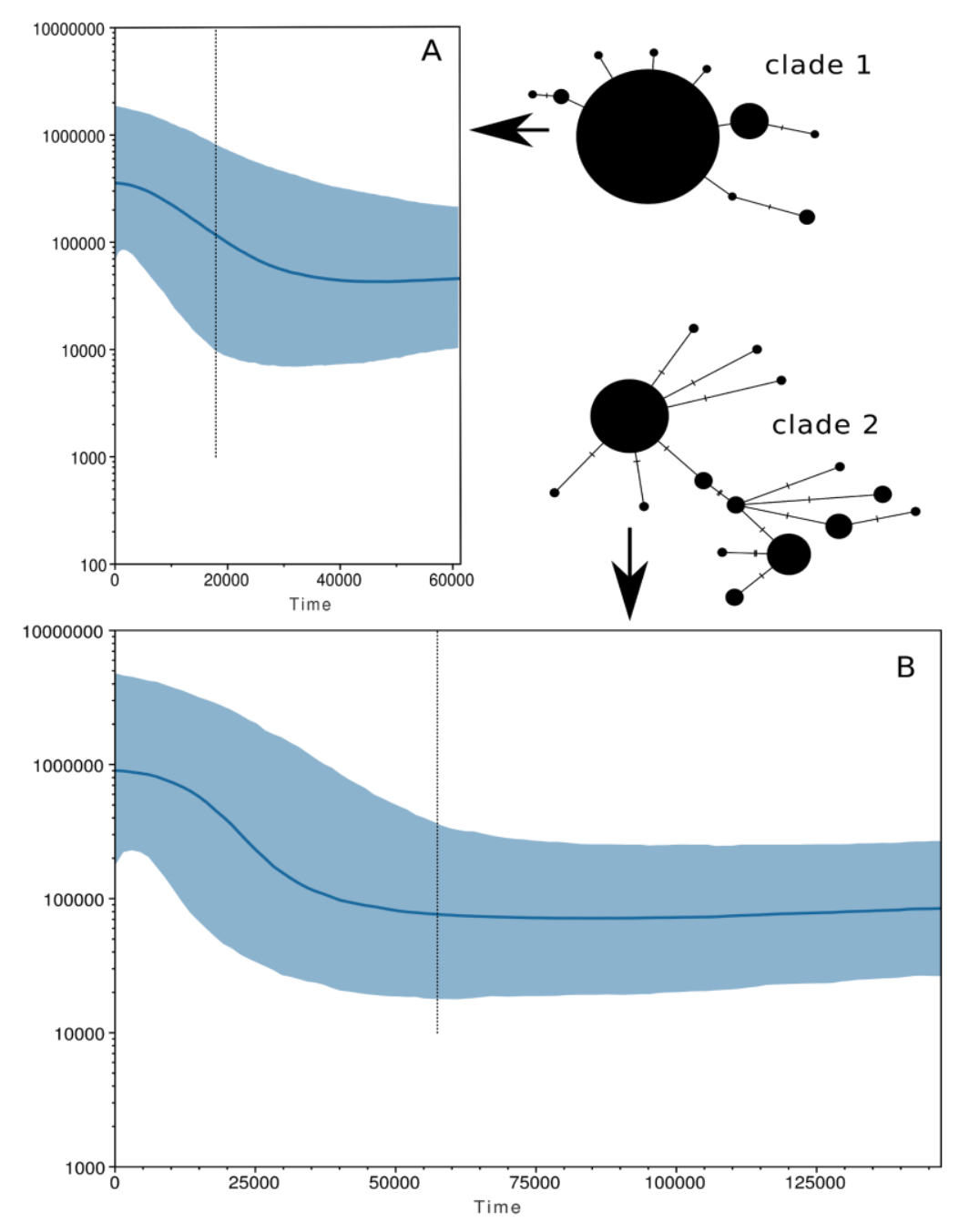

Figure 4. Bayesian Skyline Plots demographic analysis for two major Atlantic clades of Ophiura sarsii.

From the demographic analyses, we estimated the time of population expansion in clade 1 as ca. $38 \mathrm{kyr}$ BP according to mismatch analysis and ca.18 kyr BP according to the BSP analysis. Mismatch analysis also indicated similar expansion estimates (ca. $31 \mathrm{kyr}$ BP) for the major starshaped group of haplotypes in clade 2, thus showing similar patterns of demographic expansion in both lineages present in the Barents Sea. While the estimates of different approaches vary, they 
both point to the Middle and Late periods of Weichselian. These estimates are based on a mutation rate conventionally used in the studies of brittle stars (2.48\% per MY, Naughton et al., 2014; Sands et al., 2015), and representing average divergence between sister species pairs of family Ophiocomidae occuring on two coasts of Isthmus of Panama (Naughton et al., 2014). While the method of calibrating the mutation rates by estimating the divergence rate between pairs of closelyrelated species on both shores of Isthmus of Panama, that emerged ca. 3.5 MY BP, is widely used for many taxa (Kolman \& Bermingham, 1997; Donaldson \& Wilson, 1999; Lessios, 2008), in this case it is related to species from different families within the Ophiuroidea. Recent review of demographic studies of marine species (Grant, 2015) indicates that choosing a mutation rate to place a historical reconstruction of a population remains the main source of errors in mismatch and BSP analyses.

During the Last Glacial Maximum, the Barents Sea was partly or nearly completely covered by ice (Ingólfsson \& Landvik 2013). The analysis of benthic sediments and cores indicated that signatures of glaciation can be observed down to a depth of about 200 meters, and only central parts of the Barents Sea with depths more than 300 meters were ice-free and connected with the Norwegian Sea (Biryukov et al., 1988). The ice-sheet retreat most likely started during the Bølling-Allerød interstadial, i.e. ca. 15 kyr BP at western margin of the Barents Sea (Polyak et al., 1995), and this period thus most plausibly can indicate the beginning of eastward spread of subtidal marine species.

Until recently, the study of mtDNA diversity of $O$. sarsii, a widely distributed brittle star species in the North Atlantic, was limited to general barcoding projects being aimed on regional revisions of echinoderm faunas of Canada (Layton et al., 2016), Iceland (Khodami et al., 2014) and the North Sea (Laakmann et al., 2016). Our study represents an important contribution in the context of phylogeography of brittle stars in the region in line with recent studies of AtlanticMediterranean species (Pérez-Portela, Almada, Turon, 2013; Weber et al., 2014; Taboada \& PérezPortela, 2016). As a result, we present the data on the northernmost European populations of $O$. sarsii from the Barents Sea, and since sampling from other parts of the Atlantic remains predominantly qualitative and not quantitative, further studies are needed to implement more broad phylogeographic analysis on this brittle star species.

\section{Acknowledgments}

We thank all participants of the Barents Sea research cruises where brittle star samples were collected. The study was supported by Russian Fund for Basic Research (project 19-54-53028) and the National Natural Science Foundation of China (4181101341). 


\section{References}

Folmer O., Black M., Hoeh W., Lutz R., \& Vrijenhoek R. (1994). DNA primers for amplification of mitochondrial cytochrome c oxidase subunit I from diverse metazoan invertebrates. Molecular Marine Biology and Biotechnology, 3(5), 294-299.

Addison, J. A., \& Hart, M. W. (2005). Colonization, dispersal, and hybridization influence phylogeography o North Atlantic sea urchins (Strongylochntrotus droebachiensis). Evolution, 59(3), 532-543.

Anisimova, N. A. (2000). Echinodermata of the Barents Sea. In Contemporary bentic fauna of the Barents and Kara Seas (in russian) (pp. 228-347).

Biryukov, V. Y., Faustova, M. A., Kaplin, P. A., Pavlidis, Y. A., Romanova, E. A., \& Velichko, A. A. (1988). The paleogeography of Arctic shelf and coastal zone of Eurasia at the time of the last glaciation (18,000 yr BP). Palaeogeography, Palaeoclimatology, Palaeoecology, 68(2-4), 117-125.

Blanchard, A. L., Parris, C. L., Knowlton, A. L., \& Wade, N. R. (2013). Benthic ecology of the northeastern Chukchi Sea. Part II. Spatial variation of megafaunal community structure, 2009-2010. Continental Shelf Research, 67, 67-76.

Cochrane, S. K., Denisenko, S. G., Renaud, P. E., Emblow, C. S., Ambrose Jr, W. G., Ellingsen, I. H., \& Skarḥhamar, J. (2009). Benthic macrofauna and productivity regimes in the Barents Sea-Ecological implications in a changing Arctic. Journal of Sea Research, 61(4), 222-233.

Cochrane, S. K. J., Denisenko, S. G., Renaud, P. E., Emblow, C. S., Ambrose, W. G., Ellingsen, I. H., \& Skarðhamar, J. (2009). Benthic macrofauna and productivity regimes in the Barents Sea-Ecological implications in a changing Arctic. Journal of Sea Research, 61(4), 222-233. https://doi.org/10.1016/j.seares.2009.01.003

Colson, I., \& Hughes, R. N. (2007). Contrasted patterns of genetic variation in the dogwhelk Nucella lapillus along two putative post-glacial expansion routes. Marine Ecology Progress Series, 343, 183-191.

Coyer, J. A., Hoarau, G., Costa, J. F., Hogerdijk, B., Serrão, E. A., Billard, E., Valero, M., Pearson, G. A., \& Olsen, J. L. (2011). Evolution and diversification within the intertidal brown macroalgae Fucus spiralis/F. vesiculosus species complex in the North Atlantic. Molecular Phylogenetics and Evolution, 58(2), 283-296.

Coyer, James A., Hoarau, G., Van Schaik, J., Luijckx, P., \& Olsen, J. L. (2011). Trans-Pacific and trans-Arctic pathways of the intertidal macroalga Fucus distichus L. reveal multiple glacial refugia and colonizations from the North Pacific to the North Atlantic. Journal of Biogeography, 38(4), 756-771.

Dahlgren, T. G., Weinberg, J. R., \& Halanych, K. M. (2000). Phylogeography of the ocean quahog (Arctica islandica): Influences of paleoclimate on genetic diversity and species range. Marine Biology, 137(3), 487-495.

Darriba, D., Taboada, G. L., Doallo, R., \& Posada, D. (2012). jModelTest 2: More models, new heuristics and parallel computing. Nature Methods, 9(8), 772-772.

Dautov, S. S., \& Selina, M. S. (2009). Foraging conditions of planktotrophic larvae of echinoderms in the southwestern part of Peter the Great Bay of the Sea of Japan. Russian Journal of Marine Biology, 35(1), 25-33.

Djakonov, A. M. (1954). Ophiuroidea of the Seas of the USSR. Opredeliteli Po Faune SSSR [Keys to the Fauna of the USSR, Published by the Zoological Institute of the Academy of Sciences of the USSR], 55, 1. 
Edgar, R. C. (2004). MUSCLE: Multiple sequence alignment with high accuracy and high throughput. Nucleic Acids Research, 32(5), 1792-1797.

$\mathrm{Fu}$, Y. (1996). New statistical tests of neutrality for DNA samples from a population. Genetics, 143(1), 557-570.

Genelt-Yanovskiy, E., Nazarova, S., Tarasov, O., Mikhailova, N., \& Strelkov, P. (2019). Phylogeography of the temperate marine bivalve Cerastoderma edule (Linnaeus, 1758)(Bivalvia: Cardiidae) in the Subarctic: Unique diversity and strong population structuring at different spatial scales. Journal of Zoological Systematics and Evolutionary Research, 57, 67-79. https://doi.org/10.1111/jzs.12231

Grant, W. S. (2015). Problems and cautions with sequence mismatch analysis and Bayesian skyline plots to infer historical demography. Journal of Heredity, 106(4), 333-346.

Halanych, K. M., Vodoti, E. T., Sundberg, P., \& Dahlgren, T. G. (2013). Phylogeography of the horse mussel Modiolus modiolus. Marine Biological Association of the United Kingdom. Journal of the Marine Biological Association of the United Kingdom, 93(7), 1857.

Ingólfsson, Ó., \& Landvik, J. Y. (2013). The Svalbard-Barents Sea ice-sheet-Historical, current and future perspectives. Quaternary Science Reviews, 64, 33-60.

Khodami, S., Arbizu, P. M., Stöhr, S., \& Laakmann, S. (2014a). Molecular species delimitation of Icelandic brittle stars (Ophiuroidea). Polish Polar Research, 35(2), 243260.

Khodami, S., Arbizu, P. M., Stöhr, S., \& Laakmann, S. (2014b). Molecular species delimitation of Icelandic brittle stars (Ophiuroidea). Polish Polar Research, 35(2), 243260.

Kolman, C. J., \& Bermingham, E. (1997). Mitochondrial and nuclear DNA diversity in the Choco and Chibcha Amerinds of Panama. Genetics, 147(3), 1289-1302.

Krebes, L., Blank, M., \& Bastrop, R. (2011). Phylogeography, historical demography and postglacial colonization routes of two amphi-Atlantic distributed amphipods. Systematics and Biodiversity, 9(3), 259-273.

Kumar, S., Stecher, G., Li, M., Knyaz, C., \& Tamura, K. (2018). MEGA X: Molecular evolutionary genetics analysis across computing platforms. Molecular Biology and Evolution, 35(6), 1547-1549.

Kuznecov, V. V. (1963). Time period and temperature conditions for the reproduction of marine invertebrates (in Russian). Materials for a Comprehensive Study of the White Sea, 2, 32-52.

Laakkonen, H., Hardman, M., Strelkov, P., \& Väinölä, R. (2020). Cycles of trans-Arctic dispersal and vicariance, and diversification of the amphi-boreal marine fauna. Journal of Evolutionary Biology.

Laakmann, S., Boos, K., Knebelsberger, T., Raupach, M. J., \& Neumann, H. (2016). Species identification of echinoderms from the North Sea by combining morphology and molecular data. Helgoland Marine Research, 70.

Layton, K. K., Corstorphine, E. A., \& Hebert, P. D. (2016). Exploring Canadian echinoderm diversity through DNA Barcodes. PloS One, 11(11), e0166118.

Lessios, H. A. (2008). The great American schism: Divergence of marine organisms after the rise of the Central American Isthmus. Annual Review of Ecology, Evolution, and Systematics, 39, 63-91.

Li, Y., Dong, Y., Xu, Q., Fan, S., Lin, H., Wang, M., \& Zhang, X. (2020). Genetic 
differentiation and evolutionary history of the circumpolar species Ophiura sarsii and subspecies Ophiura sarsii vadicola (Ophiurida: Ophiuridae). Continental Shelf Research, 104085.

Lind, S., Ingvaldsen, R. B., \& Furevik, T. (2018). Arctic warming hotspot in the northern Barents Sea linked to declining sea-ice import. Nature Climate Change, 8(7), 634-639.

Luttikhuizen, P. C., Campos, J., Bleijswijk, J. van, Peijnenburg, K. T. C. A., \& van der Veer, H. W. (2008). Phylogeography of the common shrimp, Crangon crangon (L.) across its distribution range. Molecular Phylogenetics and Evolution, 46(3), 1015-1030. https://doi.org/10.1016/j.ympev.2007.11.011

Luttikhuizen, P. C., Campos, J., van Bleijswijk, J., Peijnenburg, K. T., \& van der Veer, H. W. (2008). Phylogeography of the common shrimp, Crangon crangon (L.) across its distribution range. Molecular Phylogenetics and Evolution, 46(3), 1015-1030.

Maggs, C. A., Castilho, R., Foltz, D., Henzler, C., Jolly, M. T., Kelly, J., Olsen, J., Perez, K. E., Stam, W., Väinölä, R., Viard, F., \& Wares, J. (2008). Evaluating signatures of glacial refugia for North Atlantic benthic marine taxa. Ecology, 89(sp11), S108-S122.

Magnúsdóttir, H., Pálsson, S., Westfall, K. M., Jónsson, Z. O., Goodall, J., \& Örnólfsdóttir, E. B. (2019). Revised phylogeography of the common whelk Buccinum undatum (Gastropoda: Buccinidae) across the North Atlantic. Biological Journal of the Linnean Society, 127(4), 890-899.

Michalsen, K., Dalpadado, P., Eriksen, E., Gjøsæter, H., Ingvaldsen, R. B., Johannesen, E., Jørgensen, L. L., Knutsen, T., Prozorkevich, D., \& Skern-Mauritzen, M. (2013). Marine living resources of the Barents Sea-Ecosystem understanding and monitoring in a climate change perspective. Marine Biology Research, 9(9), 932-947.

Naughton, K. M., O’Hara, T. D., Appleton, B., \& Cisternas, P. A. (2014). Antitropical distributions and species delimitation in a group of ophiocomid brittle stars (Echinodermata: Ophiuroidea: Ophiocomidae). Molecular Phylogenetics and Evolution, 78, 232-244.

Olsen, J. L., Zechman, F. W., Hoarau, G., Coyer, J. A., Stam, W. T., Valero, M., \& Åberg, P. (2010). The phylogeographic architecture of the fucoid seaweed Ascophyllum nodosum: An intertidal 'marine tree' and survivor of more than one glacial-interglacial cycle. Journal of Biogeography, 37(5), 842-856.

Packer, D. B., Watling, L., \& Langton, R. W. (1994). The population structure of the brittle star Ophiura sarsi Lütken in the Gulf of Maine and its trophic relationship to American plaice (Hippoglossoides platessoides Fabricius). Journal of Experimental Marine Biology and Ecology, 179(2), 207-222.

Paradis, E. (2010). pegas: An R package for population genetics with an integrated-modular approach. Bioinformatics, 26(3), 419-420.

Pérez-Portela, R., Almada, V., \& Turon, X. (2013). Cryptic speciation and genetic structure of widely distributed brittle stars (Ophiuroidea) in Europe. Zoologica Scripta, 42(2), 151169.

Piepenburg, D., \& Schmid, M. K. (1996). Brittle star fauna (Echinodermata: Ophiuroidea) of the Arctic northwestern Barents Sea: composition, abundance, biomass and spatial distribution. Polar Biology, 16(6), 383-392.

Polyak, Bl., Lehman, S. J., Gataullin, V., \& Timothy Jull, A. J. (1995). Two-step deglaciation of the southeastern Barents Sea. Geology, 23(6), 567-571.

Ravelo, A. M., Konar, B., Bluhm, B., \& Iken, K. (2017). Growth and production of the brittle 
stars Ophiura sarsii and Ophiocten sericeum (Echinodermata: Ophiuroidea). Continental Shelf Research, 139, 9-20.

Rogers, A. R., \& Harpending, H. (1992). Population growth makes waves in the distribution of pairwise genetic differences. Molecular Biology and Evolution, 9(3), 552-569.

Ronquist, F., Teslenko, M., Van Der Mark, P., Ayres, D. L., Darling, A., Höhna, S., Larget, B., Liu, L., Suchard, M. A., \& Huelsenbeck, J. P. (2012). MrBayes 3.2: Efficient Bayesian phylogenetic inference and model choice across a large model space. Systematic Biology, 61(3), 539-542.

Rozas, J., Ferrer-Mata, A., Sánchez-DelBarrio, J. C., Guirao-Rico, S., Librado, P., RamosOnsins, S. E., \& Sánchez-Gracia, A. (2017). DnaSP 6: DNA sequence polymorphism analysis of large data sets. Molecular Biology and Evolution, 34(12), 3299-3302.

Sands, C. J., O'Hara, T., Barnes, D. K., \& Martín-Ledo, R. (2015). Against the flow: Evidence of multiple recent invasions of warmer continental shelf waters by a Southern Ocean brittle star. Frontiers in Ecology and Evolution, 3, 63.

Taboada, S., \& Pérez-Portela, R. (2016). Contrasted phylogeographic patterns on mitochondrial DNA of shallow and deep brittle stars across the Atlantic-Mediterranean area. Scientific Reports, 6(1), 1-13.

Tajima, F. (1989). Statistical method for testing the neutral mutation hypothesis by DNA polymorphism. Genetics, 123(3), 585-595.

Wares, J. P., \& Cunningham, C. W. (2001). Phylogeography and historical ecology of the North Atlantic intertidal. Evolution, 55(12), 2455-2469.

Weber, A. A.-T., Stöhr, S., \& Chenuil, A. (2014). Genetic data, reproduction season and reproductive strategy data support the existence of biological species in Ophioderma longicauda. Comptes Rendus Biologies, 337(10), 553-560.

Weider, L. J., \& Hobæk, A. (2000). Phylogeography and arctic biodiversity: A review. Annales Zoologici Fennici, 217-231. 